\title{
Can Europe escape the doldrums?
}

The difficulty and delay in ratifying the Maastricht Treaty cast doubts on the soundness of the project and demand a greater sense of vision from those who would make Europe a reality.

THIS was to have been Europe's year. Not only would the single market be in effect, providing the economic benefits offered almost immediately by the Treaty of Rome, but most of the twelve member states of the European Communities (EC) would have ratified the Maastricht Treaty, mapping out progress towards "ever closer union" (as the treaty puts it). Although the single market is in being, compliance with its terms cannot yet be verified. The more substantial worry now is not so much that two countries (Britain and Denmark) have not yet ratified the treaty (and may not do so), but the suspicion that many of the governments ratifying the treaty last year would not do so this. In Europe falling apart?

The signs are not encouraging. From one end of Europe to the other, governments are paralysed by hesitancy. Germany is paying for reunification the hard way, beset by more immigrants than it can accommodate and heading for an election as well. Italy is stymied by corruption in public life. France, with a new government, has yet to declare its allegiance to EC institutions such as the Common Agricultural Policy and will dither for some time yet over the tentative deal between the EC and the United States over the proposed new arrangement under the General Agreement on Tariffs and Trade (GATT). Britain's diplomatic and political energy is dissipated by the year-long struggle to get the Maastricht bill through the House of Commons. The tangible proof of Europe's disunity is the lamentable indecision of the North Atlantic Treaty Organization over its role in the remnants of Yugoslavia.

None of this is a surprise. When it became plain that Maastricht would stick in a near-majority of European throats, this journal said it should be renegotiated. That has been borne out by much that has happened since. Thus the British government's defence of Maastricht in the House of Commons (to be followed by a similar battle in the House of Lords), on which it stakes its political survival, runs roughly on the lines: "Sure, it's a poor treaty, but ratification is symbolic only". Literally, that is true: in the monetary field, for example, there is now little chance that there will be a European Central Bank between four and six years from now, as Maastricht specifies. (Paradoxically, the goal would be more easily achievable if the deadline were tomorrow or the day afterwards, which could happen if the member states regarded the obdurate recession as a crisis best dealt with by monetary union, but there is little chance of that either.) But why should Europe be brought to a standstill because politicians have decided to battle over a piece of paper when they have more urgent matters to attend to?

Governments have painted themselves into this corner in the simple but mistaken belief that it is possible to build a coherent federation (such as the United States) or confederation (such a Switzerland) by legislating for free trade between member states and then giving a central executive committee (the European Commission) powers to ensure that traders compete on equal terms. By abreaction, most of the twelve governments have come to regard Brussels as a kind of jousting ring at which their representatives battle for national prizes, not for the broader European interest. Even Franco-German solidarity seems to be wearing thin. So who should be surprised that so little has been heard in the past few years of extending the remit of the EC towards the east? So long as people believe that the European venture is a zero-sum game, they will be fearful that new members' gains will be their loss. But was it not once believed, as recently as 1955 , that the whole would be greater than the sum of the parts?

The present crisis in European affairs could damage the prospects for science in Europe, which have been marvellously stimulated by the past few decades of growing collaboration. The commission, to its credit, has consistently made the right noises in that and some other directions. It has, for example, been a generous source of travel funds, while not all of its spending on the current chaotic fellowship programme will in the end be wasted. With further iteration, Europe's programmes in support of basic research could be distinctively enlivening for European science and thus for Europe: the whole would indeed be larger than the sum of its parts. But that will not happen if Europe tears itself apart. Science, of course, will not be the only or even the most important casualty of such an outcome. It is merely an illustration of why European governments should try to rise above the narrow nationalism that now grips them.

\section{Venter's venture}

Much of the work on the human genome may be done sooner than expected, but there will still be much to do.

DR Craig Venter's claim, at the Nature Genetics conference two weeks ago, that he may have listed 95 per cent of the genes in the human genome within the next eighteen months will, if proved true, turn many Human Genome Projects on 